\title{
Teacher Conduct: A Survey on Professional Ethics among Chinese Kindergarten Teachers
}

\author{
Zhaolin Ji \\ Nantong University, \\ Jiangsu, China
}

\begin{abstract}
Teacher professional ethics have recently become a much debated issue in China, which is in the wake of China's new population policy that ends the 'one-child' policy after 35 years of stringent enforcement. With increasingly more children enrolled in early childhood services, the quality of the teaching force is to stand a tougher test of public scrutiny. Professional ethics is an integral and pivotal component of teacher quality. Utilizing questionnaire as the data collection method, this study examines self-reported professional conduct of 437 in-service teachers from 50 kindergartens across three provinces of China. It is found that: (1) The majority of the kindergarten teachers report themselves as compliant with the professional ethics when facilitating all the daily routine activities and when working with colleagues and parents; (2) Several ethical issues exist with some kindergarten teachers such as differentiated approach to children from different backgrounds, unawareness of the importance of parents as stakeholders, and unhealthy relationship with colleagues.
\end{abstract}

Keywords: Kindergarten, professional ethics, China.

\section{The Chinese context}

Teacher professional ethics is an important and complex issue in early childhood education in China. The Ministry of Education of the People's Republic of China (2016) has recently promulgated Professional Standards for Kindergarten Teachers. The document provides that professional ethics for kindergarten teachers are the basis of meeting all professional standards required by the society, and represent kindergarten teachers' basic attitude toward education and care of children and their personal character. In China, the term 'kindergarten' refers to all early childhood services that cater to children aged 3-6 years. In the contemporary Chinese society, while the image of the early childhood education community is overall positive, there is frequent media coverage of incidents of child abuse or child neglect which is 
closely related to the lack of professional ethics among kindergarten teachers. Therefore, kindergarten teachers' professional ethics, as an integral part of kindergarten teacher quality, is an important and timely research topic in China.

\section{Literature review and the aim of the study}

Teacher professional ethics has long been a focus of teacher education research (Freeman \& Feeney, 2005; Ngang \& Chan, 2015; Schneider \& Kipp, 2015). Strike (1990) wrote extensively on curriculum that embeds education of professional ethics. While he admitted that teacher professional ethics could be trained or taught, he warned that it would be 'simply naive to suppose that instruction in ethics in teacher education programs can significantly form or reform character' (p. 48). Boon (2011) explored professional ethical dilemmas encountered by pre-service and in-service teachers in a case study. According to Snook (2003), ethical issues are pivotal and provision of ethics education for future teachers is important. Bullough's (2011) study pays particular attention to the nature of the ethical conflicts confronting teachers and explores problems, dilemmas and conflicts that are of ethical nature. Campbell (2008) suggested that teaching of ethics was neglected in teacher education. Pointing to the fact that teacher education programs are the initial place for developing teacher candidates' ethical dimensions of their chosen profession, Campbell argued for more importance to be attached to ethical education.

Further, Campbell (2008) emphasized that teacher professional ethics as part of teaching qualities was 'intangible' and therefore warranted more attention. According to Campbell (2008), teacher professional ethics 'may be perceived in the tone of voice a teacher uses to speak to a child, in the way a teacher justly adjudicates among competing needs and interests in the classroom, in the way a teacher selects resources with care, evaluates student work with' (p.357). Campbell (2008) believed that professional ethics and teaching were 'inherently compatible and unavoidably intertwined' (p.358).

Jeelani and Kumar (2015) made an attempt to develop a 55-item scale that could be used to measure professional ethics among secondary school teachers. Kumar's (2015) study on teacher professional ethics proposed what was called 'an improved case analysis' as a suitable approach for education of professional ethics for future teachers.

Maxwell and Schwimmer (2016a) provided an overview of the justifications for the inclusion of professional ethics as part of teacher education programmes. According to Maxwell and Schwimmer (2016a), researchers have a general consensus that initial teacher education should include the intentional and explicit imparting of professional ethics as an inherent component of teacher professionalism and teaching practice. 
Maxwell and Schwimmer (2016b) reported two studies that explored codes of ethics as indicators of professional ethics for teachers, with the first study applying content analysis to determine whether there is any consensus on teachers' professional responsibilities, and the second study deploying interpretive analysis to assess whether there emerge some dominant core values of professionalism in teaching. Maxwell and Schwimmer (2016b) found that there were specific limitations in using codes of ethics as the content of education of professional ethics.

With 50 teacher participants in their study, Shapira-Lishchinsky (2011) explored ethical dilemmas in critical incidents in teaching and the responses elicited by the incidents. They found that teachers chose to suppress these incidences since the unpleasant feelings were evoked. Shapira-Lishchinsky (2011) revealed what they called 'a multifaceted model' of ethical dilemmas which included for example clashing with the school rules, standards, or norms. Contextualizing in early childhood education and care settings, Taggart (2011) argued that early childhood education and care was a 'caring profession' with legitimacy, similar to care in other professions such as nursing or social work which is defined by ethical purposes. Early childhood practitioners enact an ethic of care as part of the teaching professionalism.

In summary, literature has provided sufficient evidences of the importance of teacher professional ethics, the need for education of teacher professional ethics and the tension and complexity involved in the subject of teacher professional ethics. However, there is little, if not none, research that focuses on teachers' perception of their own professional ethics. Given the particular importance of agency, reflectivity and reflexivity for the teaching profession (Ryan \& Bourke, 2013), the lack of research in the area is concerning. This research gap becomes even more apparent when it comes to early childhood teaching in China. There is scant research in the English literature that focuses on professional ethics among Chinese early childhood teachers. To address such a research gap, this study is aimed to provide a sample or specimen of the real picture of how professional ethics are interpreted and implemented among Chinese kindergarten teachers, which is expected to prompt further international research on the same topic. Focusing on several dimensions of teacher professional ethics, the study addresses the research question: How well are professional ethics enacted by kindergarten teachers in China?

\section{Methods}

The study design is questionnaire survey. The questionnaire is comprised of 29 items which come under four constructs of teacher professional ethics, that is, teachers' conduct during daily routine activities, teachers' conduct concerning colleagues, teachers' conduct in relation to 
parents, and teachers' beliefs about work ethics. The constructs were developed based on review of the key components of professional ethics in the scholarly articles and policy documents in the policy Chinese context.

Participants were sampled from kindergartens in China's rural areas across four provinces (Jiangsu, Shanxi, Hainan, and Qinghai). Several national teacher professional training sessions were utilized to deliver questionnaires. From November 2014 to November 2015, a total of 500 questionnaires were delivered using both online and paper-based surveying methods, and 463 questionnaires were returned and 437 were valid questionnaires. The response rate is $92.6 \%$, and the rate of valid questionnaires is $87.4 \%$. Survey was administered both online and paper-based.

\section{Data analysis and findings}

All raw data were entered into SPSS 20 for statistical analysis. This paper reports the descriptive results to present a general picture of the Chinese kindergarten teachers' attitude and behavior toward the four key constructs of professional ethics.

\section{Kindergarten teachers' conduct during daily routine activities}

In China, 'kindergarten daily activities' refers to various teacher-led activities throughout the day at the kindergarten including morning welcome, free time, morning tea, group activity, play time, outdoor activity, toilet time, sleep time, noon rest, afternoon tea, and pick up time. Section 22 of Kindergarten Working Regulation (Ministry of Education of the People's Republic of China, 2015) provides that kindergarten daily activities should be organized according to the educational principles with a focus on the children's own activity and children's enjoyment and learning from their free activities. Morning welcome time is important opportunity for individual interactions to take place between the teachers and the children. As shown in Table $1,64.07 \%$ of the teachers always welcomed the children and the parents at the gate of the building with a smiling face, $29.08 \%$ of the teachers welcomed in the classroom and supported those who had arrived, $4.57 \%$ of the teachers welcomed and prepared teaching material, $1.14 \%$ of the teachers were busy preparing for the day, and $1.14 \%$ of the teachers lamented that some children arrived too early or too late. Overall, during the morning welcome, the majority of teachers made effort to optimize the benefit of the morning welcome session for the children. 
Table 1 Teacher's conduct during morning welcome

\begin{tabular}{lll}
\hline Morning welcome & Frequency & $\begin{array}{l}\text { Percent } \\
\text {-age }\end{array}$ \\
\hline Welcome at the gate with smiling face & 280 & $64.07 \%$ \\
Welcome in the classroom and support other children & 127 & $29.08 \%$ \\
Welcome and prepare teaching material & 20 & $4.57 \%$ \\
Busy preparing for the day & 5 & $1.14 \%$ \\
Lament some children arrive too early or too late & 5 & $1.14 \%$ \\
Total & 437 & $100 \%$ \\
\hline
\end{tabular}

Water drink and toilet use are important elements of the daily routine activities. Section 22 of Kindergarten Working Regulation (Ministry of Education of the People's Republic of China, 2015) provides that kindergartens should include toilet training in the daily routine, and there should be no restriction on the frequency and time of the use of toilet by the children. As Table 2 shows, 57\% of the teachers reported that there was a general scheduled toilet use time but individual needs would be met, $21 \%$ of the teachers reported that there was no scheduled toilet use time and children could use the toilet at any time, $14 \%$ of the teachers reported that there was scheduled toilet time and children were assisted accordingly, and $8 \%$ of the teachers reported that children could use the toilet at any time except the group activity time.

Table 2 Teacher's conduct toward children's water drinking and toilet using

\begin{tabular}{lll}
\hline Approach to water drinking and toilet using & Frequency & Percentage \\
\hline Regular scheduled time & 61 & $14 \%$ \\
Anytime and no restriction & 92 & $21 \%$ \\
Anytime except the group activity time & 35 & $8 \%$ \\
Generally scheduled but individual needs met & 249 & $57 \%$ \\
Total & 437 & $100 \%$ \\
\hline
\end{tabular}

During the lunch time period, for children who do not want to eat lunch, $21.05 \%$ of the teachers reported that they would first spoon feed the children and then encourage them to eat on their own, $7.32 \%$ reported that they would spoon feed them, talk about the nutrition in the food, and keep on feeding for several days, $42.79 \%$ of the teachers reported that they would get to know about the child's routine at home and individualize their strategy, $28.84 \%$ of the teachers reported that they would give the child less food and encourage the child to eat on their own. Therefore, the majority of the teachers were able to provide individual support according to the needs of individual children and attach importance to development of the children's self-help ability (See Table 3). 
Table 3 Teacher's conduct when children do not eat lunch

\begin{tabular}{|c|c|c|}
\hline When children do not eat lunch & Frequency & $\begin{array}{l}\text { Percent } \\
\text {-age }\end{array}$ \\
\hline Spoon feed for several days and talk about nutrition & 32 & 7.32 \\
\hline $\begin{array}{l}\text { Spoon feed first then encourage the child to eat on } \\
\text { their own }\end{array}$ & 92 & 21.05 \\
\hline $\begin{array}{l}\text { Individualize the approach based on the child's } \\
\text { home routine }\end{array}$ & 187 & 42.79 \\
\hline $\begin{array}{l}\text { Give less food and encourage the child to eat on } \\
\text { their own }\end{array}$ & 126 & 28.84 \\
\hline Total & 437 & $100 \%$ \\
\hline
\end{tabular}

During the afternoon sleep time, $6.78 \%$ of the teachers reported that they would individualize their approach and allow the children to sleep at different times, $29.98 \%$ of the teachers reported that they would ask the children to sleep at the same time, $59.72 \%$ of the teachers reported that the majority of the children sleep at the scheduled time but exceptions would be allowed, and $4.12 \%$ of the teacher reported other approaches. Therefore, the majority of teachers were able to manage the afternoon sleep time reasonably but some teachers insisted on a rigid schedule (See Table 4).

Table 4 Teacher's conduct during the afternoon sleep time

\begin{tabular}{|c|c|c|}
\hline Conduct during the afternoon sleep time & Frequency & $\begin{array}{l}\text { Percent } \\
\text {-age }\end{array}$ \\
\hline Allow children to sleep at different times & 27 & $6.78 \%$ \\
\hline All children sleep at a scheduled time & 131 & $29.98 \%$ \\
\hline $\begin{array}{l}\text { All children sleep at a scheduled time with } \\
\text { exceptions }\end{array}$ & 261 & $59.72 \%$ \\
\hline Other approaches & 18 & $4.12 \%$ \\
\hline Total & 437 & $100 \%$ \\
\hline
\end{tabular}

As Table 5 shows, during the preparation for daily activities, $64.53 \%$ of the teachers reported that they would have prepared all the material the day before, $21.74 \%$ of the teachers reported that they would have prepared all the material for group activities, $6.64 \%$ of the teachers reported that they would prepare when they start the day, $7.09 \%$ of the teachers reported that no preparation was needed. Therefore, the majority of the teachers were able to prepare teaching materials in advance and get fully prepared for the day. 
Table 5 Teacher's conduct concerning preparedness for teaching

\begin{tabular}{lll}
\hline Conduct concerning preparedness & Frequency & $\begin{array}{l}\text { Percent } \\
\text {-age }\end{array}$ \\
\hline $\begin{array}{l}\text { Prepare the material the day before } \\
\begin{array}{l}\text { Prepare the material for group activities the day } \\
\text { before }\end{array}\end{array}$ & $\begin{array}{l}282 \\
64.53 \% \\
\text { Prepare at the beginning of the day }\end{array}$ & $21.74 \%$ \\
$\begin{array}{l}\text { No much preparation needed } \\
\text { Total }\end{array}$ & 29 & $6.64 \%$ \\
\hline
\end{tabular}

A further analysis of the data revealed age difference in the degree of preparedness. In particular, $83.50 \%$ of the teachers aged $17-25$ reported that they would have all the teaching material prepared the day before compared to $61.90 \%$ of the teachers aged $46-55$ and $58.47 \%$ of the teachers aged $26-45$ (Table 6).

Table 6 Age difference in teacher's conduct concerning preparedness for teaching

\begin{tabular}{lllll}
\hline Age & $\begin{array}{l}\text { Prepare all } \\
\text { material the } \\
\text { day before }\end{array}$ & $\begin{array}{l}\text { Prepare group } \\
\text { activities the } \\
\text { day before }\end{array}$ & $\begin{array}{l}\text { Prepare at the } \\
\text { beginning of } \\
\text { the day }\end{array}$ & $\begin{array}{l}\text { Not much } \\
\text { preparation }\end{array}$ \\
\hline $\begin{array}{l}17-25 \\
(\mathrm{~N}=103)\end{array}$ & $83.50 \%(86)$ & $13.59 \%(14)$ & $2.91 \%(3)$ & $0 \%(0)$ \\
$\begin{array}{l}26-45 \\
(\mathrm{~N}=313)\end{array}$ & $58.47 \%(188)$ & $24.28 \%(76)$ & $7.35 \%(23)$ & $9.90 \%(31)$ \\
$\begin{array}{l}46-55 \\
(\mathrm{~N}=21)\end{array}$ & $61.90 \%(13)$ & $38.10 \%(8)$ & $0 \%(0)$ & $0 \%(0)$ \\
\hline
\end{tabular}

As Table 7 shows, during the play period, $2.97 \%$ of the teachers reported that they would do their own things during play time, $18.76 \%$ of the teachers reported that they would observe children's learning and development and provide guidance during the play, $16.48 \%$ of the teachers reported that they would not step in unless there was safety concerns during the play time. Therefore, the majority of teachers were able to provide appropriate guidance while allowing the children space to explore on their own.

Table 7 Teacher's approach to children's play

\begin{tabular}{lll}
\hline Teachers' approach to children's play & Frequency & Percentage \\
\hline Do their own things & 13 & $2.97 \%$ \\
Observe for children's learning and development & 82 & $18.76 \%$ \\
Provide guidance when needed & 270 & $61.79 \%$ \\
Do not step in unless there is a safety concern & 72 & $16.48 \%$ \\
Total & 437 & $100 \%$ \\
\hline
\end{tabular}


As shown in Table 8, when asked whether they had preferred and disliked children in the class, $75.91 \%$ of the teachers answered 'yes', and $24.03 \%$ of the teachers answered 'no' and reported that they treated all the children equally. The majority of teachers were unable to treat all the children equally and were influenced by their personal preference.

Table 8 Teacher's attitude toward children

\begin{tabular}{lcl}
\hline Teachers' attitude toward children & Frequency & Percentage \\
\hline Have preferred children and disliked children & 332 & $75.97 \%$ \\
Treat all the children equally & 105 & $24.03 \%$ \\
Total & 437 & $100 \%$ \\
\hline
\end{tabular}

\section{Kindergarten teachers' conduct concerning colleagues}

As shown in Table 9, when voting for "teacher of excellence", 73.46\% of the teachers made their choice objectively and fairly, $20.59 \%$ of the teachers would vote for those were their close friends, $2.52 \%$ of the teachers would vote for themselves, and $0.46 \%$ of the teachers would vote for someone who was the least likely to be elected. Therefore, when voting for "teacher of excellence", although the majority of teachers adhered to fairness and justice, a significant number of teachers did not.

Table 9 Teacher's conduct when voting for "Teacher of Excellence"

\begin{tabular}{lll}
\hline $\begin{array}{l}\text { Teacher's conduct when voting for } \\
\text { "Teacher of Excellence" }\end{array}$ & Frequency & Percentage \\
\hline Vote fairly and honestly & 321 & $73.46 \%$ \\
Vote for their close friends & 90 & $20.59 \%$ \\
Do not vote seriously & 13 & $2.97 \%$ \\
Vote for self & 11 & $2.52 \%$ \\
Vote for the one least likely to win & 2 & $0.46 \%$ \\
Total & 437 & $100 \%$ \\
\hline
\end{tabular}

In response to innovation in teaching initiated by their colleagues, $45.99 \%$ of the teachers supported colleagues' initiative and learned from them, $39.13 \%$ of the teachers generally acknowledged the initiative without any special feeling about it, $11.21 \%$ of the teachers held that innovation would be nothing but extra work and pressure for others, $3.67 \%$ of the teachers felt jealousy and would make negative comments (Table 10). 
Table 10 Teacher's attitude toward teaching innovation

\begin{tabular}{lll}
\hline Teacher's attitude toward teaching innovation & Frequency & Percentage \\
\hline Support and see as role model & 201 & $45.99 \%$ \\
Acknowledge without special feeling & 171 & $39.13 \%$ \\
Deem it as extra work and pressure & 49 & $11.21 \%$ \\
Feel jealous & 16 & $3.67 \%$ \\
Total & 437 & $100 \%$ \\
\hline
\end{tabular}

Further analysis of the data reveals age differences. As Table 11 shows, $47.57 \%$ of the novice teachers (aged 17-25) and $46.01 \%$ of the teachers with certain years of experience (aged 26-45) would support teaching innovation and learn from it, compared to $61.90 \%$ of the retiring teachers (aged 46-55) who would acknowledge innovation generally with no particular feeling about it.

Table 11 Age difference in teacher's attitude toward teaching innovation

\begin{tabular}{lllll}
\hline Age & $\begin{array}{l}\text { Support and see } \\
\text { as role model }\end{array}$ & $\begin{array}{l}\text { Acknowledg } \\
\text { e generally }\end{array}$ & $\begin{array}{l}\text { See as work } \\
\text { and pressure }\end{array}$ & Jealousy \\
\hline $\begin{array}{l}17-25 \\
(\mathrm{~N}=103)\end{array}$ & $47.57 \%(49)$ & $33.98 \%(35)$ & $16.50 \%(17)$ & $1.95 \%(2)$ \\
$26-45$ & $46.01 \%(144)$ & $39.30 \%(123)$ & $10.22 \%(32)$ & $4.47 \%(14)$ \\
$(\mathrm{N}=313)$ & & & & \\
$46-55(\mathrm{~N}=21)$ & $38.10 \%(8)$ & $61.90(13)$ & $0 \%(0)$ & $0 \%(0)$ \\
\hline
\end{tabular}

In response to the question on scolding children, $4.35 \%$ of the teachers held that it would be okay if the children were too naughty, $37.76 \%$ of the teachers held that it was not proper but understandable, $56.75 \%$ of the teachers held that it was not okay and must be stopped, and $1.14 \%$ of the teachers held that it was part of the teacher's routine duties (Table 12).

Table 12 Teacher's attitude toward scolding children

\begin{tabular}{lll}
\hline Teacher's attitude toward scolding children & Frequency & Percentage \\
\hline Scolding is okay if the child is too naughty & 19 & $4.35 \%$ \\
Scolding is improper but understandable & 165 & $37.76 \%$ \\
Scolding is not okay and must be stopped & 248 & $56.75 \%$ \\
Scolding is part of the teacher's work & 5 & $1.14 \%$ \\
Total & 437 & $100 \%$ \\
\hline
\end{tabular}

\section{Kindergarten teachers' conduct in relation to parents}

According to Section 48 of the Chinese Kindergarten Operational Regulations (Ministry of Education of the People's Republic of China, 2016), kindergartens should work with parents and help parents to create nurturing 
and educational home environment and gain the knowledge of education and care of children. In response to the question on family-kindergarten partnership, $74.83 \%$ of the teachers held that parents were key stakeholder, $14.87 \%$ of the teachers held that family-kindergarten partnership depended more on those parents with better educational background, $2.52 \%$ of the teachers held that there was no way for parents and teachers to cooperate, $7.78 \%$ of the teachers held that family-kindergarten partnership was mainly about the kindergarten providing education to parents (Table 13).

Table 13. Teacher's belief about family-kindergarten partnership

\begin{tabular}{|c|c|c|}
\hline $\begin{array}{l}\text { Teacher's belief about } \\
\text { family-kindergarten partnership }\end{array}$ & Frequency & Percentage \\
\hline Key stakeholder & 327 & $74.83 \%$ \\
\hline Depend on parents with better education & 65 & $14.87 \%$ \\
\hline $\begin{array}{l}\text { There is no way for family-kindergarten } \\
\text { collaboration }\end{array}$ & 11 & $2.52 \%$ \\
\hline $\begin{array}{l}\text { Partnership is education of parents by the } \\
\text { kindergarten }\end{array}$ & 34 & $7.78 \%$ \\
\hline Total & 437 & $100 \%$ \\
\hline
\end{tabular}

Further analysis of the data reveals age difference. As Table 14 shows, the retiring teachers (aged 46-55) communicated with parents more effectively and were more likely to acknowledge that parents were an important partner of the kindergarten.

Table 14. Age difference in teacher's belief about family-kindergarten partnership

\begin{tabular}{lllll}
\hline Age & $\begin{array}{l}\text { Key } \\
\text { stakeholder }\end{array}$ & $\begin{array}{l}\text { Rely on better } \\
\text { educated } \\
\text { parents }\end{array}$ & $\begin{array}{l}\text { No way to } \\
\text { co-operate }\end{array}$ & $\begin{array}{l}\text { Mainly } \\
\text { education } \\
\text { of parents }\end{array}$ \\
\hline $\begin{array}{l}17-25 \\
(\mathrm{~N}=103)\end{array}$ & $79.62 \%(82)$ & $9.71 \%(10)$ & $0.97 \%(1)$ & $9.71 \%(10)$ \\
$26-45$ & $71.57 \%(224)$ & $17.57 \%(55)$ & $3.19 \%(10)$ & $7.67 \%(24)$ \\
$(\mathrm{N}=313)$ & & & & \\
$46-55(\mathrm{~N}=21)$ & $100 \%(21)$ & $0 \%(0)$ & $0 \%(0)$ & $0 \%(0)$ \\
\hline
\end{tabular}

As Table 15 shows, in response to the question on receiving gifts from parents, $6.64 \%$ of the teachers held that gifts were parents' recognition of teacher's work and teachers should accept, $82.15 \%$ of the teachers held that educating and caring the children was teachers' duty and teachers should not accept gifts from parents, $9.61 \%$ of the teachers held that teachers should accept the non-monetary gifts but not monetary gifts, $1.60 \%$ of the teachers held that teachers could accept any gift that was less than 200 Chinese dollars 
in value. The data shows that over $80 \%$ of the teachers adhered to the boundary between gifts and bribes.

Table 15. Teacher's approach to the boundary between gifts and bribes

\begin{tabular}{lcc}
\hline Boundary between gifts and bribes & Frequency & Percentage \\
\hline Teachers should accept gifts from parents & 29 & $6.64 \%$ \\
Teachers should not accept gifts from parents & 359 & $82.15 \%$ \\
Teachers should not accept monetary gifts & 42 & $9.61 \%$ \\
from parents & & \\
Teachers can accept gifts worth below $¥ 200$ & 7 & $1.60 \%$ \\
Total & 437 & $100 \%$ \\
\hline
\end{tabular}

\section{Kindergarten teachers' beliefs about work ethics}

In response to the question on work ethics, $27.00 \%$ of the teachers endorsed self-sacrificing devotion, $8.92 \%$ of the teachers endorsed working hard without complaining, $1.60 \%$ of the teachers endorsed carrying on work while sick, and $62.47 \%$ of the teachers endorsed working smartly (Table 16).

Table 16. Teacher's attitude toward work ethics

\begin{tabular}{lcc}
\hline Teacher's attitude toward work ethics & Frequency & Percentage \\
\hline Self-sacrificing devotion & 118 & $27.00 \%$ \\
Working hard without complaining & 39 & $8.92 \%$ \\
Carrying on work while sick & 7 & $1.60 \%$ \\
Working smartly & 273 & $62.47 \%$ \\
Total & 437 & $100 \%$ \\
\hline
\end{tabular}

Further analysis of the data identifies age difference in teachers' work ethics. As shown in Table 17, 42.86\% of the retiring teachers (aged 46-55) were more likely to go for sacrificing devotion.

Table 17. Age difference in teacher's attitude toward work ethics

\begin{tabular}{lllll}
\hline Age & $\begin{array}{l}\text { Self-sacrificing } \\
\text { devotion }\end{array}$ & $\begin{array}{l}\text { Working } \\
\text { without } \\
\text { complaining }\end{array}$ & $\begin{array}{l}\text { Carrying on } \\
\text { work while } \\
\text { sick }\end{array}$ & $\begin{array}{l}\text { Smart } \\
\text { growth }\end{array}$ \\
\hline $\begin{array}{l}17-25 \\
(\mathrm{~N}=103)\end{array}$ & $35.92 \%(37)$ & $4.85 \%(5)$ & $0 \%(0)$ & $59.22 \%(61)$ \\
$26-45$ & $23.00 \%(72)$ & $10.54 \%(33)$ & $2.24 \%(7)$ & $64.22 \%$ \\
$(\mathrm{~N}=313)$ & & & & $(201)$ \\
$46-55$ & $42.86 \%(9)$ & $4.77 \%(1)$ & $0 \%(0)$ & $52.38 \%(11)$ \\
$(\mathrm{N}=21)$ & & & & \\
\hline
\end{tabular}




\section{Discussion}

Our survey shows that the majority of the Chinese kindergarten teachers are capable of adhering to professional ethics during daily activities. Professional ethics are embedded in all moments of the daily activities and are visible through verbal and non-verbal language of the teachers. During the different periods of daily activities, morning welcome, group activities and play time, teachers' professional ethics are very visible. Professional ethics are an important component of teachers' professional qualities. The survey confirms that the majority of the teachers conform to the professional ethics, for example, during the morning welcome, $64.07 \%$ of the teachers waited at the gate and welcomed the parents and the children, which is a significant contributor to the children's enjoyment of the day. For water drinking and toilet using, $57 \%$ of the teachers attended to the different needs of individual children. Over $90 \%$ of the teachers provided individual support and allowed the children's independent choice during the lunch time. It is clear that the teachers had strong awareness of the importance of respect for children and were meeting the needs of individual children. There were certainly issues with some teachers. For example, over two thirds of teachers admitted that they had preferred and disliked children and only less than one fourth of teachers truly treated the children equally. Research has shown that the children are sensitive to teachers' attitude toward them, the differentiation in teacher-child relationship is not only a barrier to children's growth but also goes against the principle of social justice and equity. It is easy for the kindergarten teachers to say that they would treat all children equally, nevertheless, it is not easy to enact the equity principle.

Given the extreme importance of teamwork for early childhood education (Heikka, Waniganayake, \& Hujala, 2013), professional relationship with colleagues becomes so crucial that it is not only an ordinary element of professional qualities but also important part of the ethics. For the benefit of children, kindergarten teachers must build up healthy and constructive relationship with their colleagues. This is one of the fundamental characteristics of the nature of early childhood teaching. The majority of the teachers were able to establish professional and mutually supportive relationship with each other, for example, embracing the teaching innovation initiated by colleagues and voting for the right person for "excellence of teacher". It is notable that there were some teachers who adopted unprofessional standards and displayed negative sentiments when engaging in team activities, for example, detachment and jealousy which are in essence harmful for effective delivery of education and care of children.

In early childhood, partnership with families and parental involvement are essential and more important than any of other stages of education (Fantuzzo, et al., 2013). Professional relationship between teachers and 
parents is the basis of such partnership. The majority of the teachers adhered to the professional and ethical principles, for example, not accepting parents' monetary gifts and emphasizing the importance of parent-teacher cooperation. There were small proportion of teachers who were not able to understand the essence of parent-teacher partnership, that is, they viewed parents as the audience of teachers' talk rather than a stakeholder that would make more meaningful contribution to the education and care of children.

The study discloses some sensitive and subtle issues which are seemingly apparent but in fact hard to address in practice. These issues include: scolding children, treating children differently, being unprepared for teaching. While these conducts are against the professional ethics, due to the macro environment and the teachers past life experiences, some teachers still are not able to overcome the outdated, teacher-centred teaching philosophy that was ingrained in the traditional Chinese notion of the authority of teacher (Ma \& Tsui, 2015). Another reason for the existence of such issues could be related to the rural areas in particular. In China, although the gap between the rural and urban areas are being narrowed, in some rural and remote counties and villages, the traditional and old fashioned teaching philosophy still prevails, for example, the teachers are still seen figures who have the authority to discipline and control their students.

\section{Implications for practice and policy}

The study has implications for both practice and policy. It is important that all kindergartens promote professional ethics and minimize the cases of violating professional ethics. Due to the importance of teaching practice and reflection on teacher professional development, kindergarten leaders can encourage teachers to constantly reflect on their practice, and the reflection may take both oral (e.g., conversation, team meeting, staff appraisal) and written forms (e.g., reflective journal, pedagogical documentation, teaching stories). Also, due to the importance of teacher-child relationship to the wellbeing and all-around development of the children, the teachers need to make conscious, intentional effort to build up and maintain nurturing, responsive and reciprocal relationship with each and every child. The kindergarten leadership as well as the teaching team need to heed the tendency of having preferred and disliked children. It is important to promote and practice the principle that all children are equal. Further, maintaining professional and mutually supportive relationship within the teaching team is also an area that kindergartens can work on. Constructive, healthy, professional relationship with the teaching team not only is the foundation of team approach to early childhood education, but also contributes to the wellbeing of the teachers themselves. Since effective establishment of professional relationship between team members largely 
depends on the culture and leadership of individual kindergartens, it is important that all kindergarten leaders include this area into their daily work agenda.

At policy level, the government needs to allocate funding for the purpose of professional learning for kindergarten teachers. The current situation is that the teachers are fully occupied and have little time to attend professional learning activities. Government funding may be used to recruit relievers who can cover the jobs of those teachers who have to go off the floor and engage in professional learning. Also, government need to reinforce statutory, regulatory provisions on kindergarten teachers' professional ethics, for example, there need to be more regulations on the implementation of recently promulgated Professional Standards for Kindergarten Teachers (Ministry of Education of the People's Republic of China, 2016).

\section{Limitations and future research direction}

Due to resource constraint, the study is limited to a small size of sample. Given the importance of the research topic, future research should include more kindergarten teachers in more geographically and socioeconomically diverse areas. Another limitation of the study relates to its lack of in-depth data that may explain the underlying reasons of some phenomena. Future research may include individual, in-depth interview as data collection method.

\section{Conclusions}

In spite of the limitations, it can be concluded from the study: (1) The majority of the kindergarten teachers in China are aware of the importance of professional ethics and adhere to the ethical principles in the profession; (2) There are small percentage of kindergarten teachers who comprise on key professional ethical principles, which is due to complex social cultural context of the teaching profession in China; (3) For the benefits of all stakeholders, particularly the children, there is a need for kindergartens, society and government to work together to help kindergarten teachers improve on their knowledge, skills, and attitude, and professional ethics in particular.

\section{References:}

Boon, H. (2011). Raising the bar: Ethics education for quality teachers. Australian Journal of Teacher Education, 36(7), 76-93. doi: 10.14221/ajte.2011v36n7.2

Bullough, R. V. (2011). Ethical and moral matters in teaching and teacher education. Teaching and Teacher Education, 27(1), 21-28. doi: 10.1016/j.tate.2010.09.007

Campbell, E. (2008). The ethics of teaching as a moral profession. Curriculum Inquiry, 38(4), 357-385. doi: 10.1111/j.1467-873x.2008.00414.x

Fantuzzo, J., Gadsden, V., Li, F., Sproul, F., McDermott, P., Hightower, D., \& Minney, 
A. (2013). Multiple dimensions of family engagement in early childhood education: Evidence for a short form of the Family Involvement Questionnaire. Early Childhood Research Quarterly, 28(4), 734-742. doi: 10.1016/j.ecresq.2013.07.001

Freeman, N., \& Feeney, S. (2005). Ethics and the early childhood educator: Using the NAEYC Code. National Association for the Education of Young Children, 1509 16th Street, NW, Washington, DC 20036.

Heikka, J., Waniganayake, M., \& Hujala, E. (2013). Contextualizing distributed leadership within early childhood education: Current understandings, research evidence and future challenges. Educational Management Administration \& Leadership, 41(1), 30-44. doi: 10.1177/1741143212462700

Jeelani, B., \& Kumar, R. K. (2015). Construction and Standardization of the teachers' professional ethics scale (TPES). International Journal of Multidisciplinary Research and Modern Education, 1(1), 46-49.

Kumar, J. S. (2015). An Approach to Professional Ethics Education for Pre Service Teachers. Educational Quest, 6(1), 61.

Ma, L., \& Tsui, A. S. (2015). Traditional Chinese philosophies and contemporary leadership. The Leadership Quarterly, 26(1), 13-24. doi: 10.1016/j.leaqua.2014.11.008

Maxwell, B., \& Schwimmer, M. (2016a). Professional ethics education for future teachers: A narrative review of the scholarly writings. Journal of Moral Education, 45(3), 354-371. doi: 10.1080/03057240.2016.1204271

Maxwell, B., \& Schwimmer, M. (2016b). Seeking the elusive ethical base of teacher professionalism in Canadian codes of ethics. Teaching and Teacher Education, 59, 468-480. doi: 10.1016/j.tate.2016.07.015

Ministry of Education of the People's Republic of China. (2015). Kindergarten Working Regulation.

Retrieved

from

http://www.edu.cn/xue_qian_news_197/20130329/t20130329_923792.shtml

Ministry of Education of the People's Republic of China. (2016). Professional Standards for Kindergarten Teachers. Retrieved from http://old.moe.gov.cn/ewebeditor/uploadfile/2012/09/13/20120913155511 581.doc

Ngang, T. K., \& Chan, T. C. (2015). The importance of ethics, moral and professional skills of novice teachers. Procedia-Social and Behavioral Sciences, 205, 8-12. doi: 10.1016/j.sbspro.2015.09.004

Ryan, M., \& Bourke, T. (2013). The teacher as reflexive professional: Making visible the excluded discourse in teacher standards. Discourse: Studies in the cultural politics of education, 34(3), 411-423. doi: 10.1080/01596306.2012.717193

Schneider, A., \& Kipp, K. H. (2015). Professional growth through collaboration between kindergarten and elementary school teachers. Teaching and Teacher Education, 52, 37-46. doi: 10.1016/j.tate.2015.08.006

Shapira-Lishchinsky, O. (2011). Teachers' critical incidents: Ethical dilemmas in 
teaching practice. Teaching and Teacher Education, 27(3), 648-656. doi: 10.1016/j.tate.2010.11.003

Snook, I. (2003). The ethical teacher. Palmerston, NZ: Dunmore Press.

Strike, K.A. (1990). Teaching ethics to teachers: What the curriculum should be about. Teaching and Teacher Education, 6(1), 47-53. doi: 10.1016/0742-051x(90)90006-q

Taggart, G. (2011). Don't we care? The ethics and emotional labour of early years professionalism. Early Years, 31(1), 85-95. doi: 10.1080/09575146.2010.536948 